\title{
GLOBALISASI DALAM PENDIDIKAN
}

Wahyu Setiawan Saputera

Email : 1810111210014@mhs.ulm.ac.id

\section{Program Studi Pendidikan Sejarah Fakultas Keguruan dan Ilmu Pendidikan Universitas Lambung Mangkurat \\ Banjarmasin}

\begin{abstract}
Abstrak
Pendidikan sebagai sebuah sistem untuk proses perubahan individu memiliki nilai penting di dalam kehidupan setiap manusia. Untuk mewujudkan perubahan yang mampu menjangkau semua aspek dalam diri manusia dibutuhkan kurikulum yang mampu rnenunjangnya. Kurikulum perlu didesain agar proses kehidupan yang ada mendapat porsi yang imbang, antara aspek kognitif, afektif dan psikomotorik. Globalisasi merupakan sebuah keniscayaan dalam kehidupan berbangsa dan bernegara, hal ini sebagai bagian dan adanya proses neoliberalisme, dimana perlu disikapi dengankepala dingin. Globalisasi membawa pengaruh dalam berbagai lini kehidupan baik yang negatif maupun positif, termasuk di dalamnya adalah dunia pendidikan. Untuk menunjang dan menghadang globalisasi, maka perlu adanya strategi dalam pendidikan. Strategi itu dimaksudkan sebagai sebuah langkah yang harus dilakukan.
\end{abstract}

Kata Kunci: globalisasi, pendidikan

\section{Pendahuluan}

Pendidikan dalam arti luas adaiah proses yang berkaitan dengan upaya untuk mengembangkan pada diri seseorang mengenai tiga aspek dalam kehidupannya, yakni, pandangan hidup, sikap hidup dan keterampilan hidup. Upaya untuk mengembangkan ketiga aspek tersebut bisa dilaksanakan di sekolah, luar sekolah dan keluarga. Kegiatan di sekolah direncanakan dan dilaksanakan 
secara ketat dengan prinsip-prinsip yang sudah ditetapkan. Pelaksanaan di luar sekolah, meski memiliki rencana dan program yang jelas tetapi pelaksanaannya relatif longgar dengan berbagai pedoman yang relatif fleksibel disesuaikan dengan kebutuhan dan kondisi lokal. Pelaksanaan pendidikan dalam keluarga dilaksanakan secara informal tanpa tujuan yang dirumuskàn secara baku dan tertulis.

Dengan mendasarkan pada konsep pendidikan tersebut di atas, maka sesunguhnya pendidikan merupakan pembudayaan atau "enculturation", suatu proses untuk mentasbihkan seseorang mampu hidup dalam suatu budaya tertentu. Konsekuensi dari pernyataan ini, maka praktek pendidikan harus sesuai dengan budaya masyarakat yang akan menimbulkan penyimpangan yang dapat muncul dalam berbagai bentuk goncangan kehidupan individu dan masyarakat.

\section{Relevansi jenis/metode evaluasi yang dibahas}

Pendidikan adalah ajang pertarungan ideologis, bagaimana bukan pertarungan jika pada kenyataannya apa yang menjadi tujuan pendidikan saat ini berbenturan dengan kepentingan yang lain, lembaga pendidikan adalah wilayah di mana kesadaran diperebutkan oleh kepentingan: kepentingan untuk membebaskan manusia peserta didik dengan kesadaran dan dorongan untuk terlibat aktif dalam aktivitas yang mengarah pada kemanusiaan dengan kepentingan untuk menjadikan peserta didik hanya tunduk pada "kesadaran" yang dapat melanggengkan sistem penindasan dan menjadikan peserta didik hanya sebagai obyek dalam pembangunan budaya yang menguntungkan kekuasaan yang menindas kemanusiaan

Pendidikan berwawasan global dapat dikaji berdasarkan dua perspektif, yakni perspektif kurikuler dan perspektif reformasi. Berdasarkan perspektif kurikuler, pendidikan berwawasan global merupakan suatu proses pendidikan yang bertujuan untuk mempersiapkan tenaga terdidik kelas menengah dan profesional dengan meningkatkan kemampuan individu dalam memahami masyarakatnya dalam kaitan dengan kehidupan masyarakat dunia. Berdasarkan 
perspektif kurikuler ini, pengembangan pendidikan berwawasan global memiliki implikasi ke arah perombakan kurikulum pendidikan.

Pendidikan berwawasan global merupakan suatu proses pendidikan yang dirancang untuk mempersiapkan peserta didik dengan kemampuan dasar intelektual dan tanggung jawab guna memasuki kehidupan yang bersifat sangat kompetitif dan dengan derajat saling ketergantungan antar bangsa yang amat tinggi. Pendidikan harus mengaitkan proses pendidikan yang berlangsung di sekolah dengan nilai-nilai yang selalu berubah di masyarakat global. Oleh karena itu sekolah harus memiliki orientasi nilai, di mana masyarakat kita harus selalu dikaji dalam kaitannya dengan masyarakat dunia.

Pendidikan memiliki keterkaitan erat dengan globalisasi. Pendidikan tidak mungkin menisbikan proses globalisasi yang akan mewujudkan masyarakat global ini. Dalam menuju era globalisasi, Indonesia harus melakukan reformasi dalam proses pendidikan, dengan tekanan menciptakan sistem pendidikan yang lebih komprehensif dan fleksibel, sehingga para lulusan dapat berfungsi secara efektif dalam kehidupan masyarakat global demokratis. Untuk itu, pendidikan harus dirancang sedemikian rupa yang memungkinkan para peserta didik mengembangkan potensi yang dimiliki secara alami dan kreatif dalam suasana penuh kebebasan, kebersamaan dan tanggung jawab. Di samping itu, pendidikan harus menghasilkan lulusan yang dapat memahami masyarakatnya dengan segala faktor yang dapat mendukung mencapai sukses ataupun penghalang yang menyebabkan kegagalan dalam kehidupan bermasyarakat. Salah satu altematif yang dapat dilakukan adalah mengembangkan pendidikan yang berwawasan global.

\section{Kesimpulan}

Pendidikan sebagai sebuah sistem untuk proses perubahan individu memiliki nilai penting di dalam kehidupan setiap manusia. Untuk mewujudkan perubahan yang mampu menjangkau semua aspek dalam diri manusia dibutuhkan kurikulum yang mampu menunjangnya. Kurikulum perlu didesain agar proses 
kehidupan yang ada mendapat porsi yang imbang, antara aspek kognitif, afektif dan psikomotorik. Globalisasi merupakan sebuah keniscayaan dalam kehidupan berbangsa dan bernegara, hal ini sebagai bagian dan adanya proses neoliberalisme, dimana perlu disikapi dengan kepala dingin. Globalisasi membawa pengaruh dalam berbagai lini kehidupan baik yang negatif maupun positif, termasuk di dalamnya adalah dunia pendidikan. 


\section{Daftar pustaka}

Anis, M. Z. A., Putro, H. P. N., Susanto, H., \& Hastuti, K. P. (2020). Historical Thinking Model in Achieving Cognitive Dimension of Indonesian History Learning. PalArch's Journal of Archaeology of Egypt/Egyptology, 17(7), 7894-7906.

Anis, M. Z. A., Susanto, H., \& Mardiani, F. (2021, February). Analysis of the Effectiveness of MPBH: The Mains of Mandai as a Saving Food in Banjarmasin Community. In The 2nd International Conference on Social Sciences Education (ICSSE 2020) (pp. 89-94). Atlantis Press.

Efendi, I., Prawitasari, M., \& Susanto, H. (2021). Implementasi Penilaian Pembelajaran Pada Kurikulum 2013 Mata Pelajaran Sejarah. Prabayaksa: Journal of History Education, 1(1), 21-25.

Muslam. 2011. GLOBALISASI DALAM PENDIDIKAN (DESAIN KURIKULUM YANG HARUS DIKEMBANGKAN DALAM PENDIDIKAN DI ERA GLOBALISASI). IAIN Walisongo DPK di STAI Pati

Susanto, H. (2020). Profesi Keguruan. Banjarmasin: FKIP Universitas Lambung Mangkurat.

Susanto, H., \& Akmal, H. (2018). Efektivitas Penggunaan Aplikasi Pembelajaran Berbasis Mobile Smartphone Sebagai Media Pengenalan Sejarah Lokal Masa Revolusi Fisik Di Kalimantan Selatan Pada Siswa Sekolah Menengah Atas. HISTORIA: Jurnal Program Studi Pendidikan Sejarah, 6(2), 197-206.

Susanto, H., Irmawati, I., Akmal, H., \& Abbas, E. W. (2021). Media Film Dokumenter Masuknya Islam Ke Nusantara dan Pengaruhnya Terhadap Keterampilan Berpikir Kritis Siswa. HISTORIA: Jurnal Program Studi Pendidikan Sejarah, 9(1). 